King, R., Skeldon R. and Vullnetari, J. (2008). Internal and International Migration: Bridging the Theoretical Divide. Sussex: Centre for Migration Research, University of Sussex.

Kozlovs, M. (2014). Comparative analysis of economic migration in Serbia and Latvia in period 2008 till 2013. University of Latvia, 1-69.

Krasnopjorov, O. (2011). Cik cilvēku pameta Latviju un cik vēl pametīs? (How many people emigrated from Latvia and how many are planning to do so?). http://www.makroekonomika.lv/cikcilveku-latviju-pameta-un-cik-vel-pametis (19.12.2018).

Migration Policy Centre (2013). The politics of European Union migration governance. http://cadmus.eui.eu/handle/1814/57305?show=full (21.1.2019)

Ratha, D., Mohapatra, S., Scheja, E. (2011). Impact of migration on economic and social development: A review of evidence and emerging Issues. World Bank Policy Research Working Paper No 5558 .

European Commission (2017). Competitiveness in low-income and low-growth regions. https://ec.europa.eu/regional_policy/sources/docgener/studies/pdf/lagging_regions\%20report_en.pdf (14.1.2019)

World Bank (2017). Migration and Remittances Recent developments and outlook. https://www.worldbank.org/en/topic/labormarkets/brief/migration-and-remittances (21.1.2019)

\title{
EXPLORING LABOUR MIGRATION FROM LATVIA: GEOGRAPHIES OF ORIGIN
}

\section{Darba spēka migrācijas izpēte Latvijā: izbraukšanas ǵeogrāfija}

\author{
Elīna Apsīte-Beriṇa, Ģirts Burgmanis, Zaiga Krišjāne \\ University of Latvia, Faculty of Geography and Earth Sciences
}

Elina.apsite-berina@lu.Iv

\begin{abstract}
The aim of this study is to explore labour migration geographies in order to reveal peculiar aspects of emigration spatial distributions between core and peripheral sending regions and destination country choices. In this study the term core is considered the capital of Latvia, Rìga, and the term periphery is considered as the remaining statistical regions in Latvia as well as the receiving countries which are identified as the UK, Ireland, Germany, Norway and Sweden. The study is based on a database derived from an online survey and analysed through statistical methods.

The findings suggest that the profiles of labour migrants differ sharply in terms of geographic context in Latvia. Migrants from the core part of the country were more educated, skilled and had worked in the tertiary sector of the economy prior moving away from Latvia than their counterparts from peripheral regions. In addition, other findings show that migrants from the core are less likely to be circular migrants, but more often than not, migrants from the periphery use their own efforts to find a job in the destination country. In terms of destination country geographies, emigrants from the core more often choose Germany, Norway and Sweden, but emigrants with lower hierarchy in education and occupation levels engage more in circular movements by repeatedly going to Ireland and the UK.
\end{abstract}

This paper was supported by the project 1.1.1.2/VIAA/1/16/184.

Keywords: labour migration, core, periphery, Latvia, youth

\section{Introduction}

Sources of human capital as substantial forces in the economic development of Western countries are often attracted from poorer economies. Migration flows from 
Central and Eastern-European countries are global economic semi-peripheries and are examples of relations among core and periphery (Torok 2017). Migration from the European periphery are seen as a factor facilitating peripheralisation (Lulle 2019). Bartlett and Prica (2013) show evidence of the existence of core regions, peripheral regions and super-peripheral regions. The Low intensity of peripheral economies that are overshadowed by core regions enforces factor mobility which includes various forms of labour mobilities (Bosworth and Venhorst 2018). Analysis of migrants to the 'escalator region' in the UK (Fielding 1992) suggest that selectivity of migration relates to workers occupying lower and higher levels of the labour sector displaying the complex nature of occupational mobility (Findlay et al. 2009, McCollum et al. 2018). Spatial disparities and societal changes, in economic development and demographic characteristics, are intertwined in several ways. Economically weak regions are often affected by both age and gender selective out-migration, leading to an unbalanced demographic and to socio-economic structures (Leibert 2016; Wiest 2016) however, in the case of Latvia, both age and gender are not statistically significant pre-conditions for out-migration.

The aim of this study is to explore labour migration geographies in order to reveal peculiar aspects of emigration spatial distributions between core and peripheral sending regions and destination country choices. In this study an analysis of labour migration is used to reveal peculiar aspects for different spatial distributions of core and peripheral regions of a sending country, and which are associated with peripherality and exclusive dependance on the centres (Skeldon 1997). Furthermore, we look at the geographies of destination countries. Countries of destination were previously identified with centrality, accumulation of human resources, and connectedness (Skeldon 1997).

To study geographical aspects of out-going migration flows we use the geographical division of Latvia in two distinct regions. Firstly, we assume that core includes urban areas around Rīga - the economic center of Latvia. Secondly, periphery is considered as being all other urban and rural regions in Latvia, where economic activity is less dense (Pierīga, Kurzeme, Zemgale, Latgale and Vidzeme).

The analysis examines quantitative features of labour migrants in Latvia considering the core-periphery divide. The analysis focuses on following two specific research questions:

- What are the main features of labour emigrants from core and peripheral parts of Latvia?

- How does the core and peripheral divide translate into choice of destination?

The regional geographies of out-migration in relation to low economic activity and unemployment leading to peripheralisation tendencies are little researched thus we seek to attract more attention by exemplifying the case of Latvia. 


\section{Data and Methods}

The dataset consists of 2567 responses from Latvian emigrants in the main destination countries. The study was conducted via an online Internet-based data collection method and the questionnaire was tailor made. The rapid development of information and communication technologies allows migration scholars to adapt these methods for their research (McCollum and Apsite-Berina 2015; Oiarzabal 2012; Reips and Buffardi 2012). This particular study was conducted in 2016 and administered through the social network site (www.draugiem.lv). Acquired data was analysed using the Crosstab chi-square test. The survey reveals that the main destination countries for Latvian emigrants are the United Kingdom, Ireland, Germany, Norway and Sweden.

Figure 1 illustrates the distribution of respondents among the statistical regions of Latvia. In the case of Kurzeme, the share of young labour migrants is greater than for other regions which is also confirmed by the statistical office where the highest number of emigrants in the last three years have been registered as being from the Kurzeme region (CSP 2018).

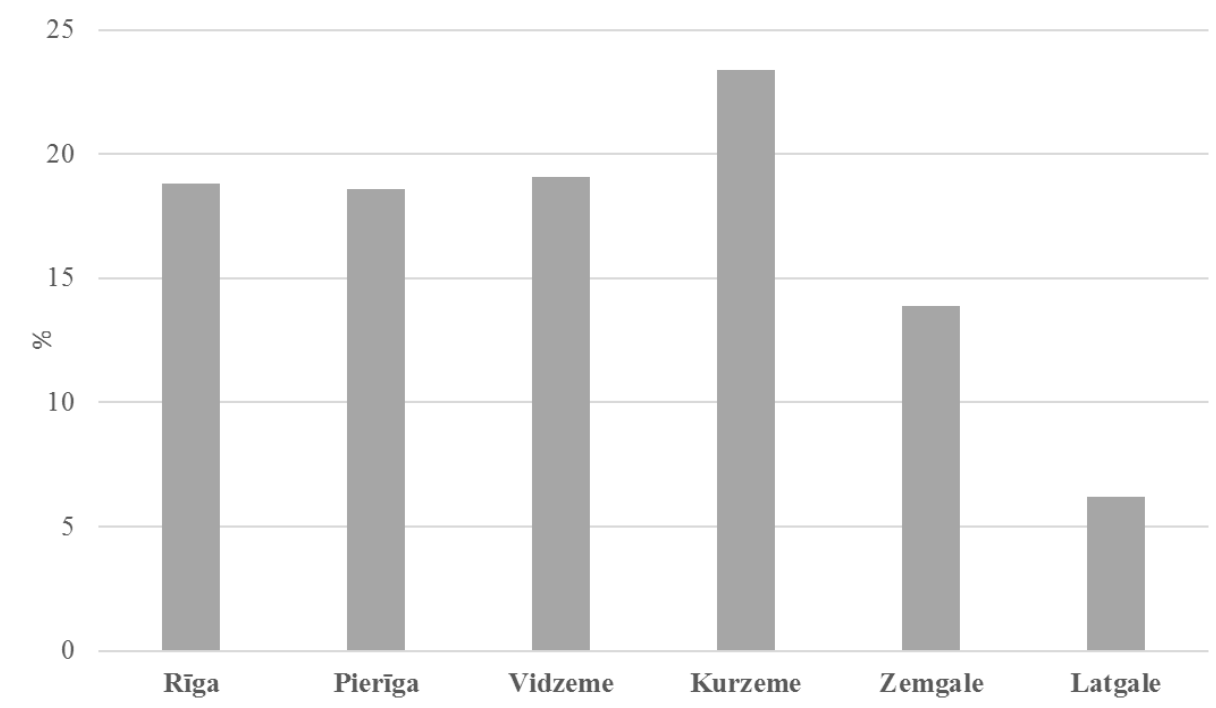

Figure 1. Labour migration from regions of Latvia (Survey 2016, n=2567)

\section{Results}

Table 1 displays the profile of labour emigrants residing in one of the top destination countries (the UK, Ireland, Germany, Norway and Sweden). The analysis disaggregates the sample according to place of origin before emigration and shows the percentage of respondents from core and peripheral territories in Latvia. 
Table 1. Characteristics of labour migrants from core and periphery locations in Latvia

\begin{tabular}{|c|c|c|c|}
\hline Variable & Core & Periphery & $\mathbf{X}^{2}$ \\
\hline & $\%$ & $\%$ & \\
\hline \multicolumn{4}{|l|}{ Gender } \\
\hline Male & $39,2 \%$ & $37,7 \%$ & \multirow{2}{*}{0,36} \\
\hline Female & $60,8 \%$ & $62,3 \%$ & \\
\hline \multicolumn{4}{|l|}{ Educational level } \\
\hline Primary education or less & $8,5 \%$ & $12,8 \%$ & \multirow{4}{*}{$63,55 * *$} \\
\hline Secondary education & $21,2 \%$ & $25,7 \%$ & \\
\hline Post-secondary non-tertiary education & $29,1 \%$ & $38,2 \%$ & \\
\hline Tertiary education & $41,2 \%$ & $23,3 \%$ & \\
\hline \multicolumn{4}{|l|}{ Age group } \\
\hline Below 35 years of age & $48,5 \%$ & $52,4 \%$ & \multirow{2}{*}{2,96} \\
\hline Above 34 years of age & $51,5 \%$ & $47,6 \%$ & \\
\hline \multicolumn{4}{|l|}{ Occupational status abroad } \\
\hline Student, pupil & $5,6 \%$ & $5,4 \%$ & \multirow{6}{*}{$\mathbf{3 4 , 8 8 * *}$} \\
\hline House-person, caring, and other not in employment & $15,4 \%$ & $15,9 \%$ & \\
\hline Manual & $20,7 \%$ & $29,0 \%$ & \\
\hline Skilled manual & $22,8 \%$ & $24,9 \%$ & \\
\hline Clerical and other administrative & $13,5 \%$ & $12,0 \%$ & \\
\hline Professional, manager & $22,0 \%$ & $12,7 \%$ & \\
\hline \multicolumn{4}{|l|}{ Occupational status in Latvia (before emigration) } \\
\hline Student, pupil & $12,9 \%$ & $17,6 \%$ & \multirow{6}{*}{$70,16 * *$} \\
\hline House-person, caring, and other not in employment & $7,9 \%$ & $12,8 \%$ & \\
\hline Manual & $8,1 \%$ & $16,3 \%$ & \\
\hline Skilled manual & $16,2 \%$ & $17,1 \%$ & \\
\hline Clerical and other administrative & $26,1 \%$ & $19,9 \%$ & \\
\hline Professional, manager & $28,8 \%$ & $16,5 \%$ & \\
\hline \multicolumn{4}{|l|}{ Recruitment channels } \\
\hline Friends and relatives & $46,1 \%$ & $59,4 \%$ & \multirow{4}{*}{$33,47 * *$} \\
\hline Recruitment agency & $12,5 \%$ & $12,6 \%$ & \\
\hline Own efforts & $29,4 \%$ & $20,4 \%$ & \\
\hline Advertisement & $12,0 \%$ & $7,6 \%$ & \\
\hline \multicolumn{4}{|l|}{ Circular migration } \\
\hline Yes & $51,0 \%$ & $42,9 \%$ & \multirow{2}{*}{$10,56 * *$} \\
\hline No & $49,0 \%$ & $57,1 \%$ & \\
\hline \multicolumn{4}{|l|}{ Country of destination } \\
\hline United Kingdom & $38,4 \%$ & $40,4 \%$ & \multirow{5}{*}{$26,77 * *$} \\
\hline Germany & $22,8 \%$ & $18,7 \%$ & \\
\hline Ireland & $12,7 \%$ & $21,1 \%$ & \\
\hline Norway & $13,5 \%$ & $11,3 \%$ & \\
\hline Sweden & $12,7 \%$ & $8,5 \%$ & \\
\hline
\end{tabular}

The differences in terms of characteristics of labour migrants between core and periphery parts of the country were confirmed by the chi-squared test (Table 1). Eight variables in total were tested. Results reveal that slightly more men have emigrated from core than from periphery, but that a higher percentage of labour emigrants from periphery are women. However, statistical analysis shows that these differences are not statistically significant, meaning that there is no gender-based difference in terms of emigration geographies from Latvia. From Table 1 it can be observed that there are also no statistically significant differences between core and periphery in terms of age group. 
Six of the analysed variables confirmed statistically significant differences among the studied groups. As it is evident from Table 1. there are differences in terms of education, occupation before and after emigration, country of destination, recruitment channels and choice of destination countries.

There are differences in terms of education level. A greater share of the surveyed labour migrants with tertiary education departed from the core. Meanwhile more migrants holding an education level lower than tertiary moved from peripheral regions (76.7\%) compared to core $(59.8 \%)$. These findings suggest that the level of investment in human capital prior to emigration has been greater among those from the core than for those residing in peripheral parts of the country.

Furthermore, occupational status also exemplifies core-periphery differences. More skilled and qualified labour migrants (professionals, managers and administrative workers) emigrated from the core. At the same time most of the manual workers departed from peripheral regions of the country. Similar findings are displayed in occupational status analysis at the destination country. Migrants who moved away from the core more often found employment consistent with their previous skills, but migrants from the periphery were more likely to become manual workers. In the case of migrants from the periphery, the majority - nearly $30 \%$ abroad are employed as manual labourers, however, before emigration they were doing clerical or other administrative jobs. Peripheral migrants in terms of occupational status positions experience a double downward shift. In addition, labour migrants from core parts of the country experience an even sharper downward occupational mobility experiencing shift between status and place (Schuster 2005). Similar to migrants from peripheral regions, also migrants from core parts abroad are often employed as manual workers $(23 \%)$. But prior to migration, the majority of respondents $(27.8 \%)$ were employed as professionals and managers.

Eastern European migrants traditionally rely on the support of informal social networks and use this as a source of information on employment opportunities. Analysis reveals statistically significant differences among labour migrants from core and periphery locations in terms of recruitment channels. The share of migrants who use friends and relatives as sources of information for employment abroad is (59\%) from periphery and $(46 \%)$ in the case of core. Another feature is that labour migrants from core parts of Latvia have relied more on their own efforts to find employment abroad that can be linked to a higher level of education and more specific requirements for employment abroad. As it was noted before, migrants from core parts experience occupational downward mobility to a much lower extent than do labour migrants from periphery locations.

Interestingly, repeated migration and circular movements are more evident among labour migrants from the periphery, but first time migrants more often come from the core. This point exemplifies migration as a strategy to overcome periodic employment issues in peripheral Latvia. First time emigrants from the core parts of Latvia emigrate mainly to access higher levels of income. 
Analysis of the geographies of labour migrants from Latvia in the receiving countries is differentiated among labour migrants from core and periphery. Overall, the variety of background among migrants from core and peripheral parts of the country show statistically significant differences in their destination countries. The largest number of labour migrants from Latvia is going towards the United Kingdom where labour migrants from periphery slightly exceed their counterparts from the core. A similar trend is also evident in the case of Ireland where migrants from the periphery slightly outnumber migrants from central parts. However, labour migrants from core parts of the country are more evident in cases of the so-called new destination countries such as Germany, Norway and Sweden.

\section{Conclusions}

This analysis allows us to identify distinctive features of labour migrants within the EU. The geographical scale of this analysis focuses on the distinction between core parts of Latvia and the peripheral regions. Similarly, the geographic approach is used to illustrate destination country choices among labour migrants from the core and the periphery.

The results suggest that there are differences as the majority of analysed aspects showed statistically significant results among labour migrants from core and peripheral parts of the country. Among the analysed respondents there was no gender and age difference when looking at the core-periphery divide contrary to other studies (Leibert 2016; Wiest 2016). Previous studies have found that younger people emigrate from peripheral parts which can be related to opportunities and life style migration (Korpela 2009), but in the case of Latvia some of the age-specific conditions can be met by migrating to the core part of the country where educational and employment opportunities are more diverse.

However, there are a number of differences among labour migrants originating from core and periphery locations in Latvia. Emigrants from the core part of the country can be characterised, firstly, as having tertiary education; secondly, to be a qualified worker before emigration (professionals, managers and administrative workers) and to be more likely to occupy a similar position also in the country of destination; thirdly, they have found employment abroad more pro-actively, are more first-time movers and have chosen destination countries such as Germany, Sweden and Norway. Overall, these are migrants with a high human capital who tend to move to 'escalator regions' (Fielding 1992) where higher levels of social mobility (Smith and Sage 2014) and occupational mobility (Findlay et al. 2009) can be accessed.

Against this backdrop, labour migrants from periphery locations mostly hold a secondary or vocational education, and before emigration are employed as clerical and other administrative workers, but once abroad to a higher extent, they concentrate their efforts in low-skilled manual work sectors thus experiencing a downward occupational mobility. Labour migrants from the periphery more often are circular migrants and as 
a country of destination they mostly choose Ireland and the UK where the strong support of friends and relatives is ever present.

More so, it is evident that labour migrants from core and peripheral parts of the country select different destinations. Reverse patterns can be observed as migrants from core parts generally hold a higher level of education and are higher in the occupational hierarchy and, as a destination country choose relatively new destinations - Germany, Norway and Sweden. By contrast, labour migrants from peripheral parts having a seconday level of education and manual labour work as a prime choice for employment abroad, have moved mostly to Ireland and the UK.

In Europe, countries with sparsely populated regions experience a population decline which is a result of working age people choosing out-migration, mainly due to the lack of employment and life experience opportunities. De-population in rural parts of the country is a concern in many countries, thus further studies on the question of non-migrants, emigrants, return migrants and immigrants are important.

\section{Acknowledgement}

This study was supported by ERDF grant 1.1.1.2/VIAA/1/16/184 and National Research Program Project Nº.VPP-IZM-2018/1-0015.

\section{Kopsavilkums}

Raksta "Darbspēka migrācijas izpēte Latvijā: izbraukšanas ǵeogrāfija” mērkisis ir izpētīt darbaspēka migrācijas ǵeogrāfiskos aspektus, analizējot emigrācijas īpatnības, kas raksturīgas izbraukšanai no centrālajiem un perifērajiem Latvijas reǵioniem, kā arī emigrantu galamērķa valsts izvēli atkarībā no viņu iepriekšējās dzīvesvietas. Analīze veikta, ņemot vērā galamērḳa valstīs (Lielbritānija, Īrija, Vācija, Zviedrija un Norvēgija) esošo Latvijas emigrantu tiešsaistes aptaujas datus. Rezultāti parāda, ka darba migrantu raksturojums krasi atšķiras atkarībā no izcelsmes vietas Latvijā. Migranti, kuri pirms emigrācijas dzīvojuši valsts ekonomiskajā centrā Rīgā, ir ar augstāku izglītību un nodarbinātības raksturu salīdzinājumā ar migrantiem no Latvijas perifērajiem reǵioniem. Turklāt migrantiem no Rīgas retāk ir iepriekšēja migrācijas pieredze, un viṇi papildus radu un draugu atbalstam darba meklējumos ārvalstīs biežāk ir proaktīvi. Galamērķa valsts izvēle emigrantiem no centra biežāk ir Vācija, Norvēgija un Zviedrija, bet emigranti, kuriem ir vidējā izglītība un zemākas prasības darba tirgū, biežāk iesaistās cirkulārajā migrācijā un atkārtoti dodas uz Īriju vai Lielbritāniju.

\section{References}

Bosworth, G. and Venhorst V. (2018). Economic linkages between urban and rural regionswhat's in it for the rural? Regional Studies, 52 (8), 1075-1085. DOI: 10.1080/00343404.2017.1339868

Centrālā Statistikas pārvalde (2018). Emigranta profils 2014. - 2016.gadā.

Fielding, A. J. (1992). Migration and social mobility: South East England as an escalator region, Regional Studies, 26 (1), 1-15.

Findlay, A., Mason, C., Houston, D., McCollum, D. and Harrison R. (2009). Escalators, elevators and travelators: The occupational mobility of migrants to South-East England, Journal of Ethnic and Migration Studies, 35 (6), 861-879.

Korpela, M. (2009). When a trip to adulthood becomes a lifestyle: western lifestyle migrants in Varanasi, India. In: Benson, M. and O’Reilly, K. (eds.) Lifestyle Migration: Expectations, Aspirations and Experiences. Ashgate: Farnham, 15-30.

Leibert, T. (2016). She leaves, he stays? Sex-selective migration in rural East Germany. Journal of Rural Studies, 43, 267-279. 
Lerch, M. (2016). Internal and international migration across the urban hierarchy in Albania. Population Research \& Policy Review, 35, 851.

Lulle, A. (2019). Balkans and Baltics: On migration as a factor of regional peripheralization. Journal of Balkan and Near Eastern Studies, $21 \quad$ (1), 2742, DOI: 10.1080/19448953.2018.1532684

McCollum, D., Liu, Y., Findlay, A., Feng, Z. and Nightingale, G. (2018). Determinants of occupational mobility: the importance of place of work, Regional Studies, 52 (12), 1612-1623.

Rérat, P. (2014). Highly qualified rural youth: why do young graduates return to their home region? Children's Geographies, 12 (1), 70-86.

Rogaly, B. (2009). Spaces of work and everyday life: Labour geographies and the agency of unorganised temporary migrant workers. Geography Compass, 3, 1975-1987.

Schuster, L. (2005). The continuing mobility of migrants in Italy: Shifting between places and statuses. Journal of Ethnic and Migration Studies, 31 (4), 757-774.

Skeldon, R. (1997). Migration and Development: A Global Interpretation. London: Longman.

Smith, P.D. and Sage, J. (2014). The regional migration of young adults in England and Wales (2002-2008): a 'conveyor-belt' of population redistribution?, Children's Geographies, 12 (1), 102-117.

Torok, I. (2017). Migration patterns and core-periphery relations from the Central and EasternEuropean perspective. European Review, 25 (3), 388-405.

Wiest, K. (2016). Migration and everyday discourses: Peripheralisation in rural Saxony-Anhalt from a gender perspective. Journal of Rural Studies, 43, 280-290.

\title{
MOBILITY MOTIVATIONS AND EXPERIENCES OF HIGHLY SKILLED LATVIANS ABROAD
}

\section{Augsti kvalificētu Latvijas emigrantu mobilitātes motivācija un pieredze ārvalstīs}

\author{
Inese Šūpule \\ University of Latvia, Institute of Sociology and Philosophy \\ inese.supule@biss.soc.lv
}

\begin{abstract}
The aim of this paper is to analyse career migration of the highly skilled from Latvia in the context of post-accession migration since the EU enlargement of 2004. Based on secondary analysis of survey data, the study addresses three empirical questions: What are the motives of these highly skilled migrants, both for the initial migratory move and future mobility? What are the structural factors influencing the decisions of the highly skilled? What kinds of jobs do they actually obtain, and how do they get those jobs? The theoretical framework of the study is a synthesis of several theories, taking into account and testing the concept of liquid migration and its applicability to the career migration of the highly skilled from Latvia. The data analysis demonstrates that the concept of liquid migration does not characterise most typical migration patterns from Latvia, especially the migration patterns of the highly skilled in STEM areas. Contrary to the dominant characteristics of liquid migration, the highly skilled often choose long-term settlement and register abroad as employees.
\end{abstract}

Keywords: career migration of the highly skilled, liquid migration, post-accession migration

\section{Introduction}

Migration patterns and trends among highly qualified specialists have been investigated in many countries. At the same time, studies on the mobility of highly 